Further and more systematic exploration appears to be necessary before it can be said that the economic possibilities of these deposits can be properly assessed. Part 3 contains a summary of information regarding certain specially selected minerals, for consideration in reviewing the actual and potential mineral resources of Tanganyika, more particularly in regard to wartime requirements.

\section{Staff Selection}

A Paper (J. Inst. Elec. Eng., 91, Pt. 1, No. 40; April 1944) by Messrs. R. C. Woods and A. S. MacDonald discusses staff selection by scientific methods, and makes reference to the designing of tests and to the means of proving their usefulness. The use of statistical methods is considered, a number of tests being described and samples given. The application of these principles to the staff selection problems in a light electrical engineering factory is described, the procedure for staffing a new department is detailed, and reference is made to the other classes of labour which are dealt with in the factory. A note on the selection of engineer apprentices is included. The last section of the paper deals with the technique of the interview. Finally, the authors mention the origin and growth of their work as indicative of its usefulness, and refer to co-operation between various departments in the factory which are concerned with personnel.

\section{School Hygiene in Peru}

According to an annotation in the September issue of the Boletin de la Oficina Sanitaria Panamericana, school hygiene in Peru includes psychobiological investigation of childhood and adolescence, school health medical supervision and physical education. A special week is also set apart for an intensive programme in health education for the whole country. During the second half of $1941,10,000$ children between six and ten years were immunized against diphtheria. Medical examination of teachers before appointment has become the general practice. Sanatorium schools for tuberculous children, some of which are built in the higher altitudes with appropriate climatic conditions, have been established. Retarded children are being given attention and transferred to special schools.

\section{Earthquakes Registered in Spain}

DuRING January 1944, twenty-nine earthquakes were registered by the seismographs at the Geophysical Observatory at Toledo. The greatest of these happened on January 16 and registered at Toledo at $00 \mathrm{~h} .02 \mathrm{~m}$. 4Is., attaining a ground amplitude of $90 \mu$ at the Observatory. The earthquake was destructive in the province of San Juan in Argentina, South America. The nearest earthquake to Toledo during the month occurred on January 7 , when $e P_{g} z$ registered at $12 \mathrm{~h}$. $31 \mathrm{~m}$. $09 \mathrm{~s}$. from an estimated epicentral distance of $230 \mathrm{~km}$.

\section{Gas Industry in Great Britain}

THE Minister of Fuel and Power has appointed the following committee of inquiry into the gas industry : Mr. Geoffrey Heyworth (chairman), Mr. Stuart Cooper, Sir Jonathan Davidson, Mr. Gavin Martin and Prof. D. M. Newitt. The secretary of the committee will be Mr. A. F. James, of the Ministry of Fuel and Power, to whom all communications should be addressed at the Gas and Electricity Division,
Ministry of Fuel and Power, New Oxford House, Bloomsbury Way, W.C.l.

The terms of reference of the committee are: "To review the structure and organization of the gas industry, to advise what changes have now become necessary in order to develop and cheapen gas supplies to all types of consumers, and to make recommendations"?

\section{Announcements}

Frankin Medals for 1944 have been awarded to Dr. W. D. Coolidge, vice-president and director of research for the General Electric Company, for his development of the X-ray tube, and to Dr. P. Kapitza, director of the Institute for Physical Problems, Academy of Sciences of the U.S.S.R., for his work on extraordinarily high magnetic fields, and for designing an efficient liquid hydrogen machine.

Dr. S. Lrvingston Smrth, superintendent of the Engineering Department at the National Physical Laboratory, Teddington, has been appointed director of research of the British Shipbuilding Research Association recently formed by the Shipbuilding Conference in close co-operation with the Department of Scientific and Industrial Research.

DR. A. J. V. UNDERwood has resigned from the position of joint honorary secretary of the Institution of Chemical Engineers which he has held for the last eight years.

Dr. R. E. G. Armattoe, director of the Lomeshie Research Centre for Anthropology and Human Biology, and honorary physician in charge of Brooke Park (E.M.S.), Londonderry, has been elected a foreign member of the American Association of Physical Anthropologists.

Dr. Charles Ockrent, who has been working during the War in the Ministry of Supply and more recently has been acting in an advisory capacity in Scotland on the application of scientific control and instrumentation in industry, has been appointed to the scientific staff of the British Drug Houses, Ltd., as manager of production and development.

ThE following appointments have been made in the Colonial Service: R. D. Linton, agricultural officer, Tanganyika, to be senior agricultural officer, Tanganyika; G. W. Nye, deputy director of agriculture, Uganda, to be director of agriculture, Nyasaland; A. S. Richardson, director of agriculture, Nyasaland, to be director of agriculture, Uganda; E. G. Staples, senior agricultural officer, Uganda, to be director of agriculture, British Honduras; A. S. Stenhouse, agricultural officer, Tanganyika, to be senior agricultural officer, Tanganyika ; W. A. Burns, G. S. Cowin, M. A. Molloy and N. R. Reid, veterinary officers, Tanganyika, to be senior veterinary officers, Tanganyika.

WE have received from the Freshwater Biological Association a copy of Scientific Publication No. 8 which takes the form of "Keys to the British Species of Aquatic Megaloptera and Neuroptera", written by D. E. Kimmins of the British Museum (Natural History). It provides an admirable account of these insects accompanied by excellent original illustrations of their chief structural features. Its low price of 1s. 6d. should ensure it being in the hands not only of entomologists but also of all students of the freshwater fauna. It can be obtained from the Director, Freshwater Biological Association, Wray Castle, Ambleside, Westmorland. 